\title{
Comparative codon usage analysis of HIV-1 and HIV-2 genomes
}

\author{
KK Vidyavijayan, S Hassan, LK Precilla, S Swaminathan, LE Hanna* \\ From 2nd International Science Symposium on HIV and Infectious Diseases (HIV SCIENCE 2014) \\ Chennai, India. 30 January - 1 February 2014
}

\section{Background}

Compared to HIV-1, HIV-2 infection is associated with slower disease progression and transmission, longer latency period and low or undetectable plasmatic viral levels. In an attempt to understand underlying reasons for the varying pathogenicity between HIV-1 and HIV-2 at the molecular level, we analyzed the differences in codon usage pattern of all nine coding genes.

\section{Materials and methods}

Thirty five full length HIV-2 genome sequences deposited during the period 1986-2008 were downloaded from LANL. The effective number of codons (NC), GC, GC3s and Relative Synonymous Codon Usage data corresponding to each gene were calculated using Codon $\mathrm{W}$ and Correspondence analysis (CA).

\section{Results}

The NC for all the nine genes ranged from $43-55.2$, indicating that the genes of HIV-2 are also poorly biased, as has been reported earlier for HIV-1, resulting in low levels of expression of these proteins in general. The NC value of the tat gene of HIV-2 was higher than that HIV-1. The CA of all nine genes revealed that the factors influencing the expression of different genes were not the same.

\section{Conclusion}

The codon usage pattern of HIV-2 is distinctly different from that of HIV-1, and appears to be majorly shaped by the genomic composition rather than translational selection. The high Nc value of tat is suggestive of a lower level of expression of the protein in HIV-2 as compared to HIV-1, implying that this could be one of

\footnotetext{
* Correspondence: hannatrc@yahoo.com
}

Department of Clinical Research, National Institute for Research in

Tuberculosis, Chennai, India the viral factors responsible for lower levels of HIV-2 replication and delayed disease progression.

Published: 27 May 2014

doi:10.1186/1471-2334-14-S3-E2

Cite this article as: Vidyavijayan et al:: Comparative codon usage analysis of HIV-1 and HIV-2 genomes. BMC Infectious Diseases 2014 14(Suppl 3):E2.
Submit your next manuscript to BioMed Central and take full advantage of:

- Convenient online submission

- Thorough peer review

- No space constraints or color figure charges

- Immediate publication on acceptance

- Inclusion in PubMed, CAS, Scopus and Google Scholar

- Research which is freely available for redistribution

Submit your manuscript at www.biomedcentral.com/submit
C Biomed Central 